\title{
Editorial comments for all three volumes
}

The research behind this book and the two others making up this mini-series was funded by the Norwegian Research Council (RCN, project no. 240448/F10). The three books trace the reception of Jerusalem and the Holy Land in Scandinavia through a millennium. The geographical term Scandinavia originates from the classical Roman author Pliny (Naturalis historia, book IV), who applied it to an island beyond the Baltic, probably identifiable with the peninsula of Sweden and Norway. In modern usage, the term is conventionally understood as the three kingdoms Denmark, Norway, and Sweden; whereas the wider term Norden (the Nordic countries) also includes Finland, Iceland, the Faroes, Greenland, and the Baltic states. Historically, there are tight cultural connections between all these countries. Their borders and mutual political constellation have changed many times during the millennium that is covered by these three books. We therefore tend to have the horizon of Norden in mind, although most of the source material discussed is Danish, Norwegian, and Swedish, and we have chosen to apply the term Scandinavia consistently. For the Middle Ages (vol. 1), we have also chosen to include Iceland and Orkney in Scandinavia because of the very tight administrative, ecclesiastical, and cultural connections with Norway.

The periodization of the three books is worth commenting on. The first volume covers the medieval period from the Christianization in the tenth and eleventh centuries, until the Protestant Reformation in the early sixteenth century. In Scandinavian historiography, the reformation (1536-37 in Denmark-Norway and 1527-1600 in Sweden) marks the watershed between the medieval and early modern periods. We have chosen to stick to this conventional periodization, as the introduction of Lutheranism significantly affected the understanding of Jerusalem. The second volume, then, covers the early modern period from the Reformation until around 1750, when Enlightenment ideas became widespread among key figures. Although it is difficult to draw a sharp line between the early modern and modern periods, Enlightenment thought, and subsequently Romanticism, engendered a second transformation of Christian cultures in general and the understanding of Jerusalem in particular. This is investigated in the third volume, which covers the period from $c .1750$ to $c .1920$. These dates are approximations, and the delimitation is further explained in the introduction to volume 3.

For references to the spoken and written vernacular of Scandinavia in the medieval period, we have chosen the term Old Norse, regardless of the authors' land of origin. Old Norse names appear slightly modernized, except from in chapters written from a philological point of view.

A note about the Norwegian capital Oslo, which is referred to in all three volumes: The city was moved westwards and renamed in 1624 after a great fire, and for almost three centuries its name remained Christiania (or Kristiania) after the Danish king Christian IV (r. 1588-1648). In 1925 the city's medieval name Oslo was introduced again. To avoid anachronistic uses of the city's name, we refer to Christiana/ 
Kristiania in the period between 1624 and 1925. The city of Trondheim is variably referred to as Nidaros, the city's medieval name. Both these names, however, have been in continuous use since the Middle Ages.

The territory that covers today's Israel and Palestine has had multiple names through the centuries. The authors shift between Palestine, The Holy Land, etc, etc, dependant on the terms used in the actual source material. Our aim has been to avoid anachronisms. For the many illustrations, the editors have worked diligently to obtain neccessary permissions to reproduce them (cf. List of Maps and Illustrations, XI-XVI). Should there still be concerns regarding image permissions, please contact the editors responsible for the respective volume. 